\title{
The role of green marketing: Insights from three airline case studies
}

\author{
Robert Mayer $^{\mathrm{a}^{*}}$, Tim Ryley $^{\mathrm{b}}$ and David Gillingwater ${ }^{\mathrm{b}}$ \\ ${ }^{a}$ Centre for Air Transport Management, Cranfield University, Cranfield, MK43 0TR, UK \\ b Transport Studies Group, School of Civil and Building Engineering, Loughborough University, \\ Loughborough, LE11 3TU, UK \\ * Tel.: +44 (0)1234 754982 \\ E-mail: r.mayer@cranfield.ac.uk
}

\section{Introduction}

Environmental marketing has become important across a range of industries. Many organisations have adapted their marketing mix to address the changes in the market (Bonini and Oppenheim, 2008). For example, The Body Shop generates a powerful brand through the focus on environmental credentials (Curtin, 2007). Consumers also become more aware of the environmental impacts of consumption and show concern for the environmental damage this causes. They expect companies to be proactive rather than reactive when it comes to climate change, as Bonini and Oppenheim (2008, p. 56) state: "Consumers want to act green, but they expect businesses to lead the way." This means that companies should focus on green marketing efforts that are attractive to consumers. This is beneficial for the companies, as more and more people prefer to purchase from companies that care for the environment (Kotler, 2011; Strategic Direction, 2013). Historically, services are seen as producing little environmental impact (Van der Zwan and Bhamra, 2003). However, Peattie (1995, p. 182) classifies transport as "dark-grey", "high-impact" services which create significant environmental issues and achieve low sustainability. This is particularly true for air transport given its growth rate and contribution to carbon emissions. Yet, companies in the service industries such as transport organisations, can draw benefits from environmental claims in their marketing messages due to the intangible nature of services, which can help these companies to position themselves in the market (Chan et al., 2006).

Companies have responded to changes in people's environmental concerns, as identified by Saha and Darnton (2005) who conclude that "companies are exploiting green issues, through communications (...) to benefit themselves and to portray a favourable corporate image." There is a strong relationship between corporate image and customer satisfaction. As such, companies need to make sure that they reinforce and actively address the corporate image in the minds of their customers (Minkiewicz et al., 2011).

The trend of increasing environmental awareness is also recognisable in air transport leisure markets, with air travellers becoming more aware of the environmental impacts of air transport and increasing expectations for more environmentally-friendly airline services (Graham, 2008). While many industries have been proactive in developing a green marketing mix, the relationship between airlines and environmental marketing is more complex. Fuel efficiency in air transport has doubled since 1975 (Somerville, 2003), yet the reduction in emissions is outstripped by the industry's growth (Graham, 2003; IPCC, 1999). Given air transport's environmental impacts, green airline products are difficult to generate. Nevertheless, the air transport industry supports self-regulation over government regulation as it is seen as "the most appropriate means by which to engineer more sustainable mobilities in air transport" (Coles et al., 2014, p. 70).

The aims of this paper are to provide an insight into how three airlines (Virgin Atlantic Airways, easyJet and Flybe) adapt their marketing mix to reduce their environmental impacts, and to show how these adaptations are communicated to the public and their passengers. With regard to the airline marketing mix, this paper will primarily focus on green communication and its relationship with green airline products and processes. 
The role of market communication with respect to green image and eco-positioning is important within the green marketing mix. Companies can influence their green brand positioning by actively communicating the environmental attributes of the brand in comparison to competitors' brands (Hartmann et al., 2005). However, the volume (i.e. how much is communicated about green credentials) has an impact on green positioning rather than whether these claims are accurate or not. Therefore some companies might be seen as less green than other companies, yet they actually might be more environmentally-friendly (Saha and Darnton, 2005). To improve the effectiveness of environmental claims, companies need to take into consideration situation specific aspects, such as environmental claim type, customer segment and service type (Chan et al., 2006).

Carlson et al. (1993) identify four key types of environmental advertising claims: product orientation, process orientation, image orientation and environmental fact. Derived from this typology, a framework for the analysis of the three case studies has been developed. Given the close link between product and processes (e.g. production technique) in airline marketing, developments in these two areas and the resulting marketing communications of these developments are grouped together. Communications addressing image orientation and environmental facts will also be discussed together, as they illustrate the understanding of environmental issues and commitment to addressing these issues. However, as shown in the case studies, some airlines focus more on image orientation rather than a combination of image and fact orientation. The case studies also cover critical aspects and negative reactions to airlines' green marketing mix. The case studies are presented in the following format: Introduction to the airlines' environmental marketing aspects; Product and process adaptations and communications; Image and fact-oriented market communications; and Criticism and negative reactions.

The next section (Section 2) discusses general developments in green airline marketing. The following section (Section 3 ) addresses the methodology. Thereafter (Section 4), the three airline case studies are presented. The final two sections discuss the managerial implications that can be drawn from the case studies, as well as the conclusions that can be drawn from the three case studies.

\section{Green Airline Marketing}

Airlines can introduce a greener service through a range of alterations to their traditional marketing mix. In its crudest form, airlines can choose certain aircraft that produce fewer emissions than others. According to the atmosfair Airline Index (atmosfair, 2011a), the type of aircraft is the second largest factor in creating $\mathrm{CO}_{2}$ efficiency of airlines after passenger load factor (i.e. increasing the number of passengers per flight at constant seat numbers). For example, fleet choice in favour of turboprops (modern propeller aircraft) over jet aircraft can reduce airlines' fuel consumption and related to that their greenhouse gas emissions. Particularly when environmental costs have to be internalised in response to government policy, not only environmental benefits can be created but also economic benefits (Ryerson and Hansen, 2010). Aircraft age is also related to emissions, with newer aircraft producing lower emissions. However research shows that aircraft age itself only contributes to less than $1 \%$ of efficiency savings (atmosfair, 2011b). Yet, there are also commercial incentives for airlines to introduce newer aircraft. These commercial advantages include an increase in reliability (Shaw, 2011) and a reduction in fuel consumption and therefore cost savings in this category as for many airlines, fuel is one of the largest cost items (Doganis, 2010). Besides this, some airports have started to introduce emission-based charges (Graham, 2014).

Airlines can also increase the number of seats without changing the size of the aircraft that are being used. By increasing the number of seats, the $\mathrm{CO}_{2}$ emissions per seat kilometre decrease (Kling and Hough, 2011). Mason and Miyoshi (2009) estimate a coefficient of -0.31 in this respect. This means that an increase of seats on an aircraft by $1 \%$ leads to a reduction in $\mathrm{CO}_{2}$ emissions per passenger kilometre of $0.31 \%$. Increasing the number of seats per aircraft is therefore one way to "green" the airline service. 
On the "production/process" side of air transport, fuel is a key component. Besides supply pressures (i.e. increasing oil prices and finite resources) and related economic incentives, biofuels can also help to address air transport related emissions. Many airlines have started to test biofuels. However, the production of biofuels for air transport is not yet on an industrial scale and creates some issues in the production process (Nygren et al., 2009). The use of biofuels can be used to reduce the carbon emissions from the industry by between $6.6 \%$ and $17.0 \%$, dependent on the type of biofuel and in conjunction with carbon pricing schemes (Sgouridis et al., 2011). Another area related to aircraft operations are schedule-based product features. Kling and Hough (2011) highlight that with increasing distance fuel efficiency increases as take-off and ascent, which are fuel intensive, represent a smaller part of the total flight. This is also shown by Mason and Miyoshi (2009) with a negative coefficient between distance and relative $\mathrm{CO}_{2}$ emissions of -0.23 . Improving the environmental sustainability of service-related airline features (e.g. on-board service) only marginally affect the environmental efficiency of airline. These product elements are usually not represented in analyses on airline environmental efficiency (e.g. atmosfair, 2011a; Mason and Miyoshi, 2009). However, particularly waste management as part of the environmental impacts from inflight service has featured in airlines' efforts to green their inflight product. A key element in this respect is improving the environmental performance through recycling (IATA, 2011). Furthermore easyJet (2008) highlights the benefit of not serving free food on board and therefore reducing on-board waste.

The communication mix plays an important role in airline marketing and more specific green airline marketing. A range of market communication tools can be used by airlines (e.g. database marketing, field sales, and advertising - Shaw, 2011). As environmental issues become more important in air transport this affects also airlines' communication strategy. Shaw $(2011$, p. 312) points out in this respect: "(Airlines) are having to lobby over environmental questions of noise and pollution in order to ensure that limitations on their freedom of action are kept to a minimum. Advertising may be able to play a subtle but useful role in positioning an airline as a good corporate citizen." While Shaw (2011) mainly refers to political lobbying and policy-makers, using advertising and the whole communication mix to address environmental credibility and concern can also be seen as useful in creating a positive eco-positioning among air travellers. Green communications in airline marketing cover a range of areas from showing general green commitment and concern on their website (e.g. Flybe, n.d.a) or in newspapers (e.g. easyJet, 2007), producing Corporate Social Responsibility Reports (e.g. British Airways, 2011/2012), publishing online videos (e.g. SAS, 2009) and press releases (e.g. Lufthansa, 2013).

Environmental pricing in airline markets is mainly centred on offering voluntary "Carbon Off-setting" schemes. There are a series of possible voluntary schemes in air transport that can are used to reduce the environmental impact of air travel. Off-setting schemes are one of the main ways how the airline sector addresses environmental challenges (Hooper et al., 2008). Credits bought in voluntary schemes usually support projects like planting trees (to store carbon) and changes in power generation, e.g. biomass or wind energy (Broderick, 2009).

It has, therefore, been shown that airlines have started to introduce green elements to their marketing mix and the possible benefits of these measures. Further analysis of green airline marketing is necessary though, to get a more in-depth understanding of how airlines introduce a green marketing mix.

\section{Methodology}

A case study can be defined as a "detailed examination of a small sample - its extreme case as single example - of an item of interest, and typically also from a particular perspective" (Tight, 2010, p. 337). Therefore a case study is less of a methodological choice per se, but rather an approach of what is studied which can comprise of quantitative or qualitative methods or both (Flyvbjerg, 2011). In this paper the sample includes three airlines and the "particular perspective" relates to green marketing, i.e. airlines' market communication, predominantly related to product, process, image and 
fact-oriented messages. The case study approach is chosen, as this type of research enables the analysis of certain phenomena in more depth and is based in a real-life context (Yin, 2009). To get a more in-depth understanding of the use of green marketing of airlines, a "multiple case design" (Yin, 2009 ) is applied. Through the selection of three airlines, a comparative design can be applied which allows to identify "distinguishing characteristics" of each case (Bryman and Bell, 2011, p. 67). As several companies are chosen, this enables to contrast airlines' approach and success of environmental marketing (including green brand images). In airline marketing and business research, multiple case designs have been used to compare airlines, as applied by Jiang (2013) and O'Connell and Williams $(2005,2006)$. Furthermore, past research also used a case study in examining impacts on airline branding (Grundy and Moxon, 2013). While case studies are common approach in airline and services marketing, so far environmental marketing has not featured much in case study research.

The analysis is based on airlines that have included green elements in their marketing mix and communicated their green credentials to customers and the public. Selecting the cases is a key stage within the development of case studies. Rather than a random selection which is often not preferable in case studies (Gray, 2014), this paper uses an "information-oriented selection" with the purpose of "maximising the utility of information from small samples (... where) cases are selected on the basis of expectations about their information content" (Flyvbjerg, 2011, p. 307). The three airlines (Virgin Atlantic, easyJet and Flybe) are selected for the case study based on the results from a quantitative survey (Mayer et al., 2012) and their proactive approach to green marketing. This previous work has shown that Virgin Atlantic and easyJet are two airlines which have a good environmental image among air passengers. These two airlines are chosen for the case studies based on their environmental image and their inclusion of green elements in the marketing mix. Furthermore, Flybe is selected as it has been proactive in developing a green marketing mix however is perceived as less environmentally friendly by passengers than the other two airlines (Mayer et al., 2012).

A case study approach often relies on multiple sources. Sources of evidence can include documentation, observations, interviews, archival records etc. (Yin, 2009). Given the aims of this paper, the case studies are based on an examination of documentary information. The use of secondary data sources enables a greater quantity of available data and provides more breadth in the analysis (Gray, 2014; Rabinovich and Cheon, 2011). An analysis on case study research in tourism by Xiao and Smith (2006) found that the most common data collection method was secondary data. Furthermore the use of single sources dominated the analysis of 76 case study papers. Documentary sources that are used to inform case studies are formal studies or evaluations of the same case, news releases, and company websites. Further, academic sources (academic journals), mass media (e.g. news clippings) and organisational reports are analysed to develop case studies (Gray, 2014; Rabinovich and Cheon, 2011; Yin, 2009). This paper is based on an analysis of documentary, secondary sources that have been published in relation to and by the three airlines. The documentary sources, as discussed above, include the following categories of secondary data sources (as adapted from Gray, 2014, p. 516):

- Personal documents: e.g. letter by the president of Virgin Atlantic

- Organisational documents: e.g. airlines' corporate social responsibility reports, press releases by air transport and environmental organisations

- Professional and technical reports: e.g. the atmosfair airline index

- Judicial records: e.g. ruling of the Adverting Standards Authority

- Visual media: e.g. reports by television stations

- Mass media: e.g. national and international newspapers

- Academic sources: e.g. peer-reviewed journal papers; subject-specific textbooks

This enables a broad and in-depth understanding of how the airlines use environmental marketing to be achieved. Based on the aims of the paper, a key focus in the analysis of the data sources was on 
the portraying of the airlines (both in the media as well as corporate communications by the airlines). The data was collected by a review of publications about the environmental initiatives of the three airlines from 2006 to 2013.

\section{Case Studies}

\subsection{Case Study: Virgin Atlantic Airways}

\section{Introduction}

Virgin Atlantic has a relatively positive environmental image among air travellers in comparison to other airlines (Mayer et al., 2012). While many airlines see environmental issues as a problem for the industry, Virgin Atlantic identifies them as an opportunity. By using green market communications, Virgin highlights its commitment to environmental issues through the investment into environmental initiatives (Kotler and Keller, 2012). As discussed, air transport is often seen as an environmentally unfriendly product, Virgin Atlantic uses its market communications to overcome this issue and portray itself as a caring organisation.

In 2007, Virgin Atlantic set out to reduce its carbon emissions per revenue tonne kilometres by $30 \%$ from 2007 to 2020 . The airline aims to achieve this through the following measures:

- "New aircraft,

- Higher load factors,

- Air traffic management efficiencies,

- Operational and maintenance,

- New technologies, and

- Lower carbon sustainable biofuels" (Virgin Atlantic, 2010, p. 2).

While this suggests a predominantly product and process approach to environmental marketing, the role of Richard Branson plays in important role in the airline's image.

\section{Product and Process Adaptations and Communications}

The largest part of Virgin Atlantic's carbon emissions savings is planned through the use of new aircraft. In this respect, Virgin Atlantic and Boeing announced the order of 15 Boeing 787 Dreamliners under the banner of an "Environmental Partnership" (Boeing, 2007). Virgin Atlantic also uses green marketing communications when it comes to the order of new aircraft. The use of new aircraft is seen by passengers as particularly effective in addressing environmental issues of air transport (Mayer et al., 2012).

While the use of biofuels only has a marginal impact on Virgin Atlantic's environmental goal (according to Virgin Atlantic's own sustainability report), this element of their green marketing mix has received considerable attention. Virgin Atlantic not only has a reputation for its environmental commitment, but also as an innovative airline (Doganis, 2010). Being the first airline to test biofuels combines the two strengths of the company. Working together with Boeing and the engine manufacturer General Electric, in February 2008, the airline was the first commercial airline to operate a non-commercial (i.e. without passengers) flight using biofuel. One of the four engines of a Boeing 747-400 was operated with a mix of traditional aircraft fuel and $20 \%$ biofuel (Marsh, 2008; Rye et al., 2010). As part of Virgin Atlantic's green communication mix, the flight was reported on in the national and international media, e.g. the Guardian (Jones and Milmo, 2008), Reuters (Hunt, 2008) and CNN.com (CNN, 2008). Furthermore, the BBC reported on this flight, including interviewing Richard Branson and the pilot (BBC, 2008). Virgin Atlantic was the first carrier to have tested biofuels, yet since then other airlines have started to test and use biofuels, including KLM, Iberia, Thomsonfly, Continental and Lufthansa (Budd and Ryley, 2012). The use of biofuels is seen by air travellers as an effective measure that airlines can introduce (Mayer et al., 2012). Therefore from a green marketing communication perspective, it makes sense for airlines to include this initiative in their green 
marketing mix. The importance (measured by the perceived effectiveness) of biofuels in green airline marketing, has also been identified by Virgin Atlantic. In October 2011, the Airline announced new developments with regard to the use of biofuels (Virgin Atlantic, 2011). This development was again publicised in the national and international media, e.g. The Times (Pank, 2011), The Guardian (Meikle, 2011) and the South China Morning Post (2011). For its efforts in using biofuels, Virgin Atlantic received in 2013 the "Sustainable Biofuels Award" in the category "sustainable aviation" (Green Power Conferences, 2013) and was the winner in the "Business Initiative" category in The Observer Ethical Awards (Buchan, 2013).

An early initiative launched by the airline was the test of so called "starting grids" in 2006. Starting grids are areas near the runway where aircraft are towed to, while waiting for take-off. This reduces the fuel consumption while aircraft are waiting on the ground. As part of its green market communications, Virgin Atlantic publicised these trials through a press release (Virgin Atlantic, 2006).

Like many other airlines, Virgin Atlantic also offers carbon off-setting schemes. An increasing number of airlines use Carbon off-setting as part to highlight their environmental commitment (Daley, 2010). As such, this provides little room for differentiation to other airlines.

\section{Image and Fact-oriented Market Communications}

Virgin Atlantic has demonstrated its environmental concerns over the last few years. However this is not unique to Virgin Atlantic, but can be noticed among other Virgin brands too and is fuelled by the founder of Virgin, Richard Branson. Kotler and Keller (2012, p. 672) address this point by highlighting: "Clearly, Branson cares about Virgin's customers and the impact his companies have on people and the planet. That's why he recently made corporate responsibility and sustainable development $(C R / S D)$ a key priority for every one of his companies". Virgin Atlantic's environmental commitments stem from a "top-down" approach driven by top-level management which, therefore, plays an important part of the company's strategy. The role of Richard Branson is important in Virgin's marketing communication, by "linking the service to a tangible person" (Wilson et al., 2008, p. 412). Branding is a key element for Virgin Atlantic to differentiate itself from its competitors. So far in the airline sector only a few airlines have managed to establish themselves as differentiated brand (Shaw, 2011). Virgin Atlantic achieved this through the successful use of public relations (PR) activities and advertising (Holloway, 2008). With regard to environmental marketing, Virgin Atlantic particularly applies PR techniques to communicate its green credentials.

Virgin Atlantic's market communication is more image- than fact-oriented with a strong focus on creating a positive green brand image rather than identifying environmental "facts". Virgin Atlantic's environmental efforts are particularly centred on the activities and media presence of its founder Richard Branson. Apart from press releases on some of its environmental activities and its "Sustainability Report" and webpages, there are few other environmental initiatives portrayed. However, Virgin Atlantic's approach to environmental marketing mainly lies in identifying new opportunities to address its environmental impacts and being a key innovator in this area. This is in line with its wider marketing strategy to introduce novel product ideas and its use of Richard Branson as a key reference for these developments.

\section{Criticism and Negative Reactions}

In March 2008, the airline was criticised in The Times for "quietly abandoning" the idea of starting grids. The article also quotes critics who claim that Virgin's initiatives are "greenwash" with little real environmental benefits (Webster, 2008, p. 23). Richard Branson responded to the article in a letter published in The Times by dismissing the claim that the airline had abandoned the plan of starting grids. The airline's founder refers to difficulties in implementing this measure, yet highlights the valuable data gained from the test. In the letter, Branson (2008, p. 18) defends Virgin Atlantic's attitude towards the environment: "It is easy to attack companies who are genuinely trying to make an environmental difference. Virgin Atlantic is experimenting more than any other airline in the world, and 
our fuel efficiency per flight is improving as a result." This relates to Kotler and Keller's (2012) point that Richard Branson "clearly" cares about the environment. This is illustrated by Branson's emphasis on "genuinely trying to make an environmental difference". The example of starting grids shows that while the airline is proactive in reducing its environmental impact, this is not without criticism. This indicates that companies need to carefully plan their green marketing communication to avoid claims of greenwash. This is particularly difficult in the airline sector, due to the environmentally unsustainable nature of airline operations. Branson's statement also shows that Virgin Atlantic tries to differentiate itself from other airlines through its environmental commitments. When it comes to actual environmental performance though, Arjomandi and Seufert (2014) find in a study on environmental efficiency of 48 airlines, that Virgin Atlantic is among the ten worst performing airlines in the sample. This demonstrates the loose relationship between environmental image and efficiency.

As biofuels are often seen as controversial (Grayson, 2011), Virgin Atlantic highlighted the careful selection of the alternative sources, to not compete with food production (Marsh, 2008; Rye et al., 2010). While the 2008 biofuel test flight was addressed in the previously mentioned media, these sources also reported on criticism of this test. For example the Guardian (Jones and Milmo, 2008, p. 11) quoted a comment from a representative of Friends of the Earth: "Biofuels are a major distraction in the fight against climate change. There is mounting evidence that the carbon savings from biofuels are negligible. If Virgin was really serious about reducing the aviation industry's impact on the environment it would support calls for aircraft emissions to be included in the climate change bill." This highlights that the portraying in the media with regard to Virgin Atlantic's environmental efforts has not only been positive but also brought up negative aspects. Greenpeace (2008) accused the airline, referring to its biofuel tests, of "greenwash" and highlighted the negative aspects of "first generation" biofuels. The controversy around biofuels makes its use in green marketing more difficult than other methods, yet as discussed it is popular by airlines and passengers.

\subsection{Case Study: easyJet}

\section{Introduction}

Another airline that has a strong focus on environmental developments in air transport is easyJet. easyJet is perceived as an environmentally-friendly airline, and has the best environmental image among the low-cost airlines in the survey reported by Mayer et al. (2012). In the past the airline's market communication strongly focussed on environmental messages. This has also been identified by Holden (2009) when referring to easyJet using their environmental credentials in their flight magazine.

In the last few years, easyJet's attitude towards the environment seems to have changed, with environmental concerns becoming less important in their communication strategy. This change in strategy coincides with the departure of Andy Harrison as CEO who put significant effort into green marketing communications. As with Virgin Atlantic, the environmental agenda was "top-down" driven, yet Andy Harrison does not have the same brand association as Richard Branson has with Virgin Atlantic. Similarly to Virgin Atlantic, associations between the airline and its founder Stelios Hajiloannou can also be identified for easyJet. However in the easyJet case, it cannot be seen as a "personality brand" (Strategic Direction, 2010, p. 29), nor does this brand association drive the airline's environmental agenda. However in the case of easyJet's, Andy Harrison's proactive attitude has shown clear commitment to environmental concerns. Recent changes in easyJet's green marketing mix cannot only be noticed when analysing the airline's website. For example, easyJet removed the reference to the positive environmental impacts of not serving free food from its green market communication.

\section{Product/Process Adaptations and Communications}

One of the most high-profile developments in green airline product development is easyJet's introduction of the "easyJet ecoJef" in 2007. In its press release the airline announced the following: 
"easyJet has today become the first airline to outline the environmental requirements that must be met by the next generation of short-haul super-clean aircraft; and unveiled its design of what such an aircraft could look like for operation by 2015. Dubbed the 'easyJet ecoJet', the aircraft would need to be $25 \%$ quieter and would emit $50 \%$ less $\mathrm{CO}_{2}$ and $75 \%$ less $\mathrm{NO}_{x}$ than today's newest aircraft (the 737 and A320 families of aircraft)" (easyJet, 2007). The market communications regarding the ecoJet particularly focussed on the reduction of atmospheric $\left(\mathrm{CO}_{2}\right.$ and $\left.\mathrm{NO}_{\mathrm{X}}\right)$ as well as noise pollution. This is an unusual move of an airline developing a new aircraft rather than traditional aircraft manufacturers, however easyJet claimed that "the 'easyJet ecoJet' is realistic and it is achievable" (easyJet, 2007). easyJet's move received a widespread media coverage in a range of UK media, including: The Guardian (Milmo, 2007), Daily Mail (2007), The Telegraph (Millward, 2007), The Independent (Prosser Deputy, 2007) and Liverpool Echo (Hodgson, 2007). Furthermore, The Guardian also published an interview with Andy Harrison, the easyJet CEO at the time, on YouTube in January 2009 in which the ecoJet was discussed. By April 2014 this video received over 8,000 hits (The Guardian, 2009). This shows that both national and local media reported on this environmental initiative and therefore creates a certain exposure of easyJet's green commitments among the public. The ecoJet seemed to have been one of the key green product developments of easyJet. Originally easyJet (2007) claimed that it would be possible for the ecoJet to be in operation by 2015. Yet in the last few years it has not further featured any of easyJet's marketing communication. The "Sustainability" pages of the website still refer to the ecoJet under their "Environmental Code" (easyJet, 2013):

1. To be environmentally efficient in the air

2. To be environmentally efficient on the ground

3. To lead in shaping a greener future for aviation, for example: shaping future aircraft design - for example, the ecoJet

4. easyJet high efficiency $=$ lower emissions $=$ low fares

While the ecoJet is mentioned, no further indication on its development is given. The Annual Report 2012 does not refer to the ecoJet in the "Corporate Responsibility / easyJet and the environment" section, while it was featured in the airline's Annual Report 2008. The Annual Report 2012 seems to indicate that the idea of the ecoJet is shelved, as the airline states: "(...) we continue to focus on being as efficient as possible and making steady gains, rather than outlining eye catching initiatives that in reality would have little impact" (easyJet, 2012). While easyJet does not directly refer to the ecoJet, the presentation of the ecoJet in 2007 could be seen as an "eye catching initiative".

Another product innovation that the airline has implemented is the use of single-engine taxiing at some airports. Under this procedure, for taxiing at airports, only one engine is used with reduces emissions. However this also has positive commercial impacts through lower fuel costs and engine wear (Budd and Ryley, 2012).

\section{Image/Fact-oriented Market Communications}

The airline highlighted its environmental commitment by stating "easyJet is already setting the environmental standard in the airline industry" (easyJet, 2007). In its messages, easyJet liked to portray itself as a proactive airline when it comes to environmental commitments. An example of easyJet's green communication was the use of a nearly full-size newspaper advertisement of the airline. Another example is a comment titled "Airlines must play their part in saving the planef" written by Andy Harrison (CEO of easyJet at the time) in the Financial Times in 2007. In this comment, Harrison (2007, p. 15) makes the point that "(...) airlines have an obligation to maximise their environmental efficiency." With regard to easyJet's role in the industry, Harrison (2007, p. 15) claims that the airline intends "to play leading role in improving the environmental performance of (the) industry." As publicity can create creditability (McCartney, 2008), easyJet's focus on publicity and public relations can be partly attributed to its environmental image. 
Besides using newspaper advertisements focussing on the general public, the airline also used to highlight its positive environmental attitude to visitors of its website. On the website in September 2010, a tab labelled "Fly greener/Environment" stood out from the other tabs through different colouring and its prominent position as the second tab in the banner (easyJet, 2010). In September 2010, easyJet was the only airline in a sample of twelve airlines (Bmi, bmibaby, British Airways, Eastern Airways, easyJet, Flybe, KLM, Ryanair, Thomas Cook Airlines, Thomson Airways, Virgin Atlantic and Wizz Air) where an environmental theme featured the homepage in a prominent position. The only other airline that also had an environmental message on the homepage was KLM, however this message was less noticeable and towards the bottom of the homepage and therefore less of a key feature of the homepage. However, when reviewing easyJet's website in 2013, it could be noticed that environmental messages have disappeared from the prime position on the homepage. In 2013, visitors to the easyJet website have to scroll down to find a link to the "Sustainability" pages of the airline. Not only has the reference to environmental issues moved further down on the homepage, but also it is only one of several links under the "About easyJef" heading, which draws little attention to this topic. Purely analysing the change in the web content of the airline suggests that environmental issues and the proactive approach to this topic changed over time, becoming less important for the airline. However in an analysis of over 20 low-cost airlines Coles et al. (2014) find that easyJet's website was the most comprehensive website regarding airlines Corporate Social Responsibility activities.

Analysing easyJet's "Corporate Responsibility / easyJet and the environment" section in its Annual Report 2012, some features stand out when comparing the content with, for example, British Airways' "Corporate Responsibility Report 2011/2012". British Airways mainly addresses its own achievements, future plans and cooperation with different stakeholders to reduce its environmental impact. While easyJet (2012) also addresses its own achievements in reducing its environmental impact, the low-cost carrier adopts a more critical approach - both with regard to its own performance and the industry in general. In the environmental section of easyJet's Annual Report 2012, the airline points out that business incentives are a key driver it its environmental agenda. This is manifested through the following two statements (easyJet, 2012):

- "Fuel is our largest single cost item, so we are heavily incentivised to minimise its use and therefore $\mathrm{CO}_{2}$ emissions.

- Environmental concerns have a significant impact on public policy towards aviation, from restrictions on airport expansion to passenger taxes. It is therefore in our own interest to ensure that both we and the wider industry properly address environmental concerns."

Through these statements the company acknowledges that in its environmental commitments it is not purely guided by some form of altruism or "corporate social responsibility" but that the business objectives (i.e. cost reduction and less government interference) also play a significant role. Similar findings are also discovered by Lynes and Dredge (2006) in their case study on SAS. easyJet is also critical of its own environmental achievements as well as that of the industry as a whole. While the company points out that it managed to reduce its $\mathrm{CO}_{2}$ emissions over the last ten years, it also admits that from 2011 to 2012 its emissions slightly rose from $84.6 \mathrm{~g}$ per passenger kilometre to $85.5 \mathrm{~g}$ (easyJet, 2012). With regard to the overall industry performance the company states: "Aviation emissions have increased steadily over time, despite significant improvement in environmental efficiency - the growth in air traffic has outweighed the efficiency gains. (...) This is clearly unsustainable and needs to change going forward" (easyJet, 2012). The airline clearly acknowledges that the current situation in air transport is not sustainable (fact-oriented) and therefore further actions are necessary to address this issue (image-oriented). This is in stark contrast to Ryanair's CEO, who at one point denied the existence of climate change (Hickman, 2010). easyJet's comments can be linked to Ottman's (2011) argument for "credibility" in green marketing. Having a more "honest" and open attitude towards environmental issues might create more credibility when it comes to portraying its own achievements and environmental concerns. 


\section{Criticism and Negative Reactions}

Despite its environmental efforts and publicity, it needs to be noted that easyJet has also come under scrutiny by the media and the UK Advertising Standards Authority (ASA) for its environmental claims. Referring to the BBC3 television programme "Britain's Embarrassing Emissions", Pearce (2009) discusses "easyJet's carbon claims", stating "It's greenwash, of course" and suggests readers to contact the ASA if greenwash continues on the easyJet website. With regard to complaints to the ASA, the advertising regulator upheld a complaint that an advertisement, containing the claim "easyJet emits 22\% less $\mathrm{CO}_{2}$ ", was misleading (Advertising Standards Authority, 2008). Also an easyJet newspaper advertisement was also subject to complaint to the ASA, arguing that a figure of $1.6 \%$ of aviation's contribution to climate change was too low and therefore misleading. However the ASA did not uphold the complaint. The organisation Consumers International (2009) awarded easyJet in the international Bad Company Awards 2009 "for continuing to claim that travelling on an easyJet plane is better for the environment than driving a hybrid car" highlighting easyJet's greenwashing practices. The airline also has been accused of greenwashing with regard to the ecoJet, with campaigners from Friends of the Earth arguing "It seems more of a speculative airline wish list than a firm proposal. There are no plans by either Boeing or Airbus to produce such an aircraft, and it incorporates some very advanced technologies which I think are going to be many years away" (Dyer cited in Robbins, 2007, p. 4). The airline's environmental credentials were also subject to an analysis by Channel 4 (FactCheck: How green is EasyJet?) which was published on the TV channel's website. The airline received a "FactCheck rating" of " 3 " on a scale from 0 to 5 with the lower end of the scale suggesting more credibility while the higher end suggesting misrepresentation of the claims. In their analysis, the television channel acknowledges the airline's drive to bring down carbon emissions per passenger. Yet at the same time points out that the airline is responsible for an overall increase in passenger numbers, therefore proposing a rather mediocre result for their overall environmental credibility (Channel 4 News, 2007).

In the past, easyJet has put significant effort into green marketing messages. This can be both witnessed on its homepage in 2010, their newspaper advertisements and the development of the ecoJet. Despite some claims of greenwashing, the results from a survey underline that this is also recognised by passengers, giving the airline a relatively good environmental image and ecopositioning.

\subsection{Case Study: Flybe}

\section{Introduction}

Flybe has also been proactive in addressing environmental concerns. The company includes environmental messages in its market communication strategy. Flybe developed a green marketing message under the title "Low-cost but not at any cost" (Flybe, n.d.a). The company has put substantial effort into its environmental marketing messages, yet the results rather are ambiguous. Results from previous research show that Flybe only ranks midfield between the best and worst ranked airlines with the same score as bmibaby (Mayer et al., 2012). In comparison, bmibaby's fleet was significantly older and less fuel efficient than Flybe's fleet. However, an analysis by Hayward and Carbery (2007, p. 43) concludes: "Flybe (has) visibility for 'eco-friendly airline'" as the airline "is taking the opportunity to cleverly differentiate itself in a highly competitive, low-cost travel market."

\section{Product/Process Adaptations and Communications}

Flybe produced leaflets with the title "Message from Jim French : Flybe's commitment to the environment. Low-cost but not at any cost." These leaflets include information on the company's investments into more sustainable operations as well as "eco-labels" for the different aircraft the airline operates. The company introduced "eco-labels" in 2007 and claims to be the first airline to have introduced eco-labels for its fleet. The labels are also displayed as part of the booking process, which makes it a very visible element of the green marketing communication process. Furthermore the labels are shown on its aircraft and onboard literature (Flybe, n.d.b). With regard to eco-labels, there 
is a need to create "credibility", "objectivity" and "reliability" of eco-labels (Laforet, 2010; Ottman, 2011). Flybe addressed this issue by engaging an external assessor (Deloitte \& Touche LLP) to assure the validity of the eco-labels (Deloitte \& Touche, 2007). The airline provides guidelines on how these eco-labels are developed as well as a methodology for other airlines to produce their own labels (Flybe, n.d.c). As part of Flybe's green communication, the company also addresses the environmental friendliness of their fleet. Using their eco-labels for the different aircraft Flybe operates, customers are able to identify the environmental impact (with regard to noise, $\mathrm{CO}_{2}$ emissions and fuel consumption). In the leaflets, the company also refers to the use of turboprop aircraft: "When Flybe decided to invest in the Q400 and become one of the world's biggest operator of turboprop aircraft, we did so in the teeth of the rest of the industry who were moving to small jets. What this data proves is that Flybe was right, both economically and environmentally, to invest in these aircraft" (Flybe, n.d.d). The company actively highlights the environmental advantages of turboprop aircraft. Flybe's environmental communications is mainly centred on its "green" fleet and eco-labelling. Apart from focussing on their fleet and on eco-labelling, Flybe also concentrates its green marketing efforts on offering Carbon Off-setting schemes.

\section{Image/Fact-oriented Market Communications}

Similarly to easyJet, also Flybe (n.d.a) accepts the role of air transport in the climate change debate by stating on its website: "We support the view that human activity, including air travel, is contributing to global climate change and we accept that, as Europe's largest regional airline, we have a responsibility to reduce the carbon emissions produced by our aircraft." This statement covers both, fact-oriented as well as image-oriented content by providing an independent factual statement ("air travel is contributing to global climate change") and associating the company with an environmental cause ("we have a responsibility to reduce the carbon emissions produced by our aircraft") which are in line with Carlson et al.'s (1993) typology of environmental claims. Flybe's environmental attitude has also been reported on in the mass media, e.g. in 2010 The Daily Telegraph reported: "Reducing the environmental impact of air travel has been a cornerstone of Flybe strategy for several years" (Dixon, 2010, p. 8). Flybe (n.d.e) underlines its green image by listing its awards (including environmental awards) on its website. In the period from 2008 to 2010 the company claims to have received seven environmental awards from different organisations. Environmental awards can act as a signal to the public with regard to the company's strong environmental performance and also impact on its market valuation (Klassen and McLaughlin, 1996). The "Low-cost but not at any cost" campaign includes painting some of its aircraft with this message. Airlines use aircraft liveries to generate a positive perception of the airline's brand (Budd, 2012). In the case of Flybe, the aim is to generate a positive green brand image, by using green colours and apply the airline's core environmental message to the fuselage. Furthermore, Flybe supports the European Union Emissions Trading System (EU ETS) (Flybe, n.d.f). This is in line with many other European low-cost airlines that are in favour of the EU ETS, while full-service network carriers generally are more sceptical of this policy (AEA, 2011; ELFAA, 2011).

\section{Criticism and Negative Reactions}

Flybe has put a considerable amount of financial resources into their environmental marketing efforts. The company invested about $\$ 400,000$ in their eco-labelling and Carbon Off-setting scheme, in addition to $\$ 2$ billion in renewing their fleet (Ezard, 2008). Evaluating the impact of these efforts highlights mixed results. Research shows that Flybe is not seen as a leader in environmental performance by passengers, holding an eco-positioning that is average in comparisons to other airlines (Mayer et al., 2012). Therefore with regard to measuring the effectiveness of its green marketing measures it can be argued that the company has not been successful in translating their investments into a leading eco-positioning among airlines. Although Flybe has received several environmental awards, the growing number of different awards makes it more difficult for consumers to appreciate and understand the meaning of environmental awards (Font and Tribe, 2001). Hayward and Carbery's (2007) suggestion that Flybe differentiates itself from other low-cost airlines by using 
environmental marketing is therefore difficult to follow, particularly as easyJet also addresses environmental issues in their marketing mix and generates a significantly better eco-positioning than Flybe. This highlights the difficulty for airlines to achieve a good eco-positioning, despite extensively focussing on this issue.

As with Virgin Atlantic and easyJet, also Flybe has been criticised by environmental groups. The development of its eco labels have been referred to as "greenwash" by Friends of the Earth, particularly as most of Flybe's destinations can be reach by other modes of transport (Osborne, 2007). Coles et al. (2014) identify that, while Flybe produces a Corporate Social Responsibility (CSR) policy, it does not provide any aspirations or targets for the future but rather provides a historic review of its achievements. The ambiguous elements of Flybe's environmental approach illustrates that environmental images of airlines sometimes can be perceived as fuzzy and not clear.

\section{A comparison between the airlines and managerial implications}

\section{Positioning and Market Orientation}

The case studies of Virgin Atlantic, easyJet and Flybe demonstrate that airlines have started to include environmental aspects to their marketing mix over the last few years. "Market-orientation" can be a source of competitive advantage, if companies are market oriented but their competitors are not (Hunt, 2010). As environmental issues are becoming more important for customers, particularly in postrecession markets (Flatters and Willmott, 2009; Grant, 2008; The Co-operative Group, 2012), it can be expected that airlines which are more "market-oriented" (i.e. adapt their marketing mix to include environmental aspects) achieve a competitive advantage over those who are not. Green marketing can become a tool for companies to differentiate and position them in the market (Strategic Direction, 2013). In some respect this has been confirmed with Virgin Atlantic achieving good scores for environmental friendliness. By addressing environmental issues, the airline has been able to also generate a positive image for environmental friendliness and therefore contributing to green brand equity. Hunt (2010, p. 422) points out that market orientation "will promote proactive innovation" which can also be found in Virgin Atlantic's strategy as an innovative company. Therefore, the airline might find it easier than others to show innovation in its green marketing mix. easyJet too, has put considerable effort into green marketing initiatives in the past, which translates into a good ecopositioning in the market. By anticipating green consumerism and portraying its green concerns, the airline has been able to generate a green brand image which supports the airline's brand equity. With regard to Flybe, this airline does not follow the example of Virgin Atlantic and easyJet. Flybe, like the other airlines, has included environmental aspects in its marketing mix. However its eco-positioning is mediocre in comparison to other airlines (Mayer et al., 2012). Therefore, the airline was not able to use market orientation (i.e. focusing on green consumer needs) to develop a competitive advantage. Implementing market-orientation is expensive as it required significant investments in identifying market developments (Hunt, 2010). The case of Flybe illustrates that these investments need to be targeted at areas that consumers understand and appreciate. Furthermore it must be noted that Flybe is smaller than the other two airlines and therefore would find it more difficult to communicate its green initiatives more widely. A similar disadvantage for smaller firms was also identified by Chang and Chen (2013, p. 1068) in the Taiwanese manufacturing industry, who found a firm-size advantage with respect to "green organisational identity, (...) and green innovation performance."

Company culture (often supported at Senior Executive level like Andy Harrison in the case of easyJet or Richard Branson in the case of Virgin Atlantic) can also positively affect the green image of transport companies. Senior management in other services sectors can benefit from the lessons learned in the airline sector by providing a leading role in generating a positive environmental image. It has been shown in the cases of Virgin Atlantic and easyJet (while Andy Harrison was CEO), that the green agenda was driven by senior management. This is also supported by research, which shows that a strong environmental culture within a company drives company benefits (Fraj et al., 2011). There is a danger for easyJet though, that environmental goals become watered down. This 
can become particularly an issue as environmental strategies need to be long-term (Fraj et al., 2011; Strategic Direction, 2013). Different strategies between the airlines with regard to environmental marketing could create bigger differences in the environmental image between airlines and in the associated benefits.

\section{Product/Process Adaptations and Communications}

The green initiatives introduced by airlines include changes to the airlines' product design (e.g. choice of aircraft type), the testing of biofuels, and innovative aircraft operations (e.g. Virgin Atlantic's "starting grids"). However it can be noted that not all initiatives have been successful or continued for a longer period of time. This can be both witnessed with regard to easyJet's ecoJet and Virgin Atlantic's starting grids. Both initiatives were introduced with significant media coverage, yet were then stopped with limited comment from the airlines. As such, some airlines apply a "trial-and-error" approach to green airline marketing. With regard to green product development, it can be suggested that Flybe has not addressed key issues that are deemed as important by air travellers. This can be recognised in its promotion of propeller aircraft as a more environmentally-friendly option to jet aircraft. This is perceived as a less effective measure to address the environmental impacts of aviation (Mayer et al., 2012).

Product and process developments in green marketing play a key role in the airline industry. From an ecological perspective these are necessary to reduce emissions and noise. However there are also marketing benefits as certain developments (e.g. biofuels) are particularly appreciated by customers. Airlines need to study and identify those changes to their product and processes that gives them a leverage over their competitors.

\section{Image/Fact-oriented Market Communications}

A key element of all three airlines' marketing mix is the use of green marketing communications i.e. communicating the airline's green credentials to their customers and the public. Generating awareness of green credentials is an important driver for green marketing activities. It has been shown that green market communication varies between the three airlines. Virgin Atlantic particularly focuses on PR activities of its founder Richard Branson and its website. easyJet used a range of different communication strategies, from advertising in newspapers, press releases and a prominent feature on its website. However, with regard to easyJet its green focus has reduced in the last few years, with environmental issues currently playing a less important role in its market communication. Of the three airlines, Flybe used a more traditional approach to green market communications by producing hard copy leaflets. This reduces the coverage of its green credentials in comparison to other green communications (e.g. newspaper advertisement or television coverage). However, the airline refers to its environmental initiatives on its website.

The analysis of the airline sector has shown the importance of communicating environmental developments. It is noticeable in the three case studies that particularly easyJet and Flybe tend to include more fact-oriented messages than Virgin Atlantic. Both airlines accept and recognise the impact of air travel on the environment in their market communications. However, all three airlines heavily focus on image-oriented messages that are supposed to portray them as an environmentallyfriendly and conscious company.

\section{Criticism and Negative Reactions}

The case studies demonstrate that market orientation is a key element when implementing a green marketing mix. It is necessary that those measures introduced by airlines are also perceived to be effective in addressing the environmental impacts of air transport. Therefore airlines need to undertake market research to establish the most useful way and measures to establish a green marketing mix. It needs to be considered though that any measures introduced can lead to claims of greenwash, especially from environmental groups. While passengers seem to be less critical currently, any negative publicity needs to be avoided and whenever possible mitigated. Furthermore, 
passenger, do not like companies to make profits out of environmental issues. Airlines need to be aware that with increasing use of green messages, they will face a more sceptical consumer base (Grant, 2008), which will require an adjustment to their green communications. Many airlines that have introduced a green marketing mix have been accused of greenwash. Therefore the selection of green marketing initiatives is important from that perspective and airlines need to be prepared to counter claims of greenwash. This is a common feature among all three airlines.

\section{Conclusions}

The paper has highlighted the developments of three UK airlines, Virgin Atlantic, easyJet and Flybe, that are proactive in addressing environmental issues in their marketing mix. While promoting green products is an important aspect, this might be insufficient in the long-term. A key issue for companies is to develop green marketing further to include their green mission into their overall company strategy (Strategic Direction, 2013).

While there is some commonality between the airlines in the case studies (e.g. carbon off-setting schemes), each of the airlines is also characterised by relatively unique features in their green marketing mix. Virgin Atlantic's key features are its innovative approach to this subject, together with the extensive use of Richard Branson in their market communications. Innovation has also played some importance for easyJet (e.g. ecoJet), yet one differentiating feature was its (self-) critical attitude towards the environmental impacts of air transport. In the case of Flybe, their environmental marketing seems to follow a more traditional approach, using eco-labels and highlighting the benefits of its aircraft.

Introducing environmental initiatives is important in the development of a green brand image, but there are other latent factors that affect the eco-positioning of airlines. It can be suggested that the scale of the airline, PR activities and market communication strategy affect the eco-positioning in this sector. This finding is also supported by Saha and Darnton (2005), who demonstrate that the volume of communication affects a company's green position. The case studies highlight that introducing green marketing initiatives is complex. It is important to communicate the right content to customers and the general public. Previous research findings have identified that green marketing needs to be situation specific (Chan et al., 2006). The case studies show that each airline focuses on unique elements of their green marketing mix. Furthermore the environmental reputation of an industry also has an impact on how to develop a green marketing mix (Leonidou et al., 2013). As indicated previously, air transport is often seen as an environmentally unfriendly industry. This makes it more difficult for airlines to develop a green marketing mix. Nevertheless, there is evidence from different sectors that a focus on green marketing is beneficial to companies in the long-term (Fraj et al., 2011; Grant, 2008; Leonidou et al., 2013; Strategic Direction, 2013). Particularly in the case of easyJet, with the ongoing economic recession in 2008 and 2009 and the departure of Andy Harrison as CEO, the company has reduced its environmental activities. This approach might be too short-sighted and opportunistic. While green consumerism has slowed down during the recession, it is expected to recover and accelerate in future (Flatters and Willmott, 2009).

The three case study airlines are based in the United Kingdom, the largest air passenger market in the European Economic Area (Eurostat, 2013). However, similar trends can be recognised in other countries. For example, Scandinavian countries have a strong focus on environmental issues and this can be identified in the green marketing mix of the largest carrier in that region, SAS. The airline is characterised by a strong internal culture that aims at reducing the environmental impacts (Lynes and Dredge, 2006). Airlines from countries where environmental issues are less predominant in the market place can use these three airline case studies to identify best practice examples.

The developments at easyJet emphasise that green airline marketing is not static but evolves and changes over time, both with regard to the scope and intensity in marketing terms as well as the 
development of new ideas. Future research in green airline marketing needs to take account of the changing landscape of the aviation industry.

\section{References}

Advertising Standards Authority (2008), "ASA Adjudication on easyJet Airline Co Ltd", available at: http://www.asa.org.uk/Rulings/Adjudications/2008/7/easyJet-Airline-Co-Ltd/TF_ADJ_44608.aspx (accessed 14 April 2014).

AEA (2011), "Striving for an ETS that supports a sustainable aviation sector", available at: http://www.aea.be/assets/documents/positions/ETS\%20Paper_April\%2028. (accessed 14 April 2014).

Arjomandi, A. and Seufert, J. H. (2014). An evaluation of the world's major airlines' technical and environmental performance. Economic Modelling, Vol. 41, pp. 133-144.

Atmosfair (2011a), Atmosfair Airline Index 2012. Atmosfair, Berlin.

Atmosfair (2011b), Atmosfair Airline Index: Documentation of the methodology. Atmosfair, Berlin.

BBC (2008), "Virgin jet in 'biofuel' flight", available at: http://news.bbc.co.uk/player/nol/newsid_7260000/newsid_7261200/7261207.stm?bw=bb\&mp=wm \&asb $=1 \&$ news $=1 \& \mathrm{~ms} 3=22 \& \mathrm{~ms}$ javascript=true\&bbcws $=2$ (accessed 14 April 2014).

Boeing (2007), "Boeing and Virgin Atlantic Announce 787 Order, Environmental Partnership", available at: http://www.boeing.com/news/releases/2007/q2/070424a_nr.html (accessed 24 March 2013)

Bonini, S. and Oppenheim, J. (2008), "Cultivating the Green Consumer", Stanford Social Innovation Review, Fall 2008, pp. 56-61.

Branson, R. (2008), "Virgin's green plans”, The Times, 13th March 2008, p. 18.

British Airways (2011/2012), "Corporate Responsibility Report 2011/2012", available at: http://d2zax00nj39hb2.cloudfront.net/wp-content/uploads/1925_BA_CRR_v101.pdf (accessed 14 April 2014).

Broderick, J. (2009), "Voluntary carbon offsetting for air travel", in Gössling, S. and Upham, P. (Eds.), Climate Change and Aviation; Issues, Challenges and Solutions, Earthscan, London.

Bryman, A. and Bell, E. (2011), Business research methods, Oxford University Press, Oxford.

Buchan, K. (2013), "The Observer Ethical Awards winners - interactive", available at: http://www.theguardian.com/observer-ethical-awards/interactive/observer-ethical-awards-winners (accessed 14 April 2014).

Budd, L. C. S. (2012), "The influence of business models and carrier nationality on airline liveries: An analysis of 637 airlines", Journal of Air Transport Management, Vol. 23, pp. 63-68.

Budd, L. C. S. and Ryley, T. (2012), "Chapter 3 An International Dimension: Aviation" in: Ryley, T. and Chapman, L. (Eds.), Transport and climate change, Emerald, Bingley.

Carlson, L., Grove, S. J. and Kangun, N. (1993), "A Content Analysis of Environmental Advertising Claims: A Matrix Method Approach", Journal of Advertising, Vol. 22 No. 3, pp. 27-39.

Chan, R. Y. K., Leung, T. K. P. and Wong, Y. H. (2006), "The effectiveness of environmental claims for services advertising", Journal of Services Marketing, Vol. 20 No. 4, pp. 233-250

Chang, C. and Chen, Y. (2013), "Green organizational identity and green innovation", Management Decision, Vol. 51 No. 5, pp. 1056-1070.

Channel 4 News, (2007), "FactCheck: How green is EasyJet", available at: http://www.channel4.com/news/articles/society/environment/factcheck+hho+green+is+easyjet/509 642.html (accessed 24 March 2013).

CNN (2008), "Biofuel-powered jet makes test flight", available at: http://edition.cnn.com/2008/BUSINESS/02/24/flight.biofuels/ (accessed 14 April 2014).

Coles, T., Fenclova, E., and Dinan, C. (2014), Corporate social responsibility reporting among European low-fares airlines: Challenges for the examination and development of sustainable mobilities. Journal of Sustainable Tourism, Vol. 22 No. 1, pp. 69-88.

Consumers International (2009), "Audi, BP, easyJet and Microsoft slammed for green washing in international Bad Company Awards 2009", available at:

http://www.consumersinternational.org/news-and-media/press-releases/2009/12/audi,-bp,-easyjetand-microsoft-slammed-for-greenwashing-in-international-bad-company-awards-2009 (accessed 14 April 2014).

Curtin, T. (2007), Managing Green Issues. 2nd ed., Palgrave Macmillan, Basingstoke.

Daily Mail (2007), "Easyjet unveils the 'ecoJet' - the environmentally-friendly plane", available at: http://www.dailymail.co.uk/sciencetech/article-462021/Easyjet-unveils-ecoJet---environmentallyfriendly-plane.htm (accessed 14 April 2014). 
Daley, B. (2010), Air Transport and the Environment. Ashgate, Farnham.

Deloitte \& Touche (2007), "Assurance", available at: http://www.flybe.com/pdf/deloitte_assurance.pdf (accessed 14 April 2014).

Dixon, G. (2010), "Flying high in turbulent times: High-quality customer service, innovation and a commitment to environmental responsibility are fundamental to the ongoing success of Flybe", The Daily Telegraph, 7 October 2010, p. 8.

Doganis, R. (2010), Flying off Course: Airline Economics and Marketing, 4th ed., Routledge, London.

easyJet (2007), "The "easyJet ecoJet": to cut CO2 emissions by $50 \%$ by 2015 ", available at: http://corporate.easyjet.com/media/latest-news/news-year-2007/14-06-07a-en.aspx (accessed: 14 April 2014).

easyJet (2008), "Annual Report and accounts 2008", available at: http://corporate.easyjet.com/ /media/Files/E/Easyjet-PIc-V2/pdf/investors/result-centerinvestor/easyJet_ar081.pdf (accessed 14 April 2014).

easyJet (2010), "Homepage", available at www.easyjet.com (accessed 09 September 2010).

easyJet (2012), "Annual Report and Accounts 2012: easyJet and the environment", available at: http://2012annualreport.easyjet.com/corporate-responsibility/environment.aspx (accessed: 27 January 2013).

easyJet (2013), "Sustainability", available at:

http://corporate.easyjet.com/sustainability.aspx?utm_source=ej_CMS\&utm_medium=en_Homepag e\&utm_term=Sustainability\&utm_content=StaticLink_AEJ4\&utm_campaign=Footer (accessed 26 January 2013).

ELFAA (2011), "ELFAA welcomes ECJ Judgment on EU ETS Directive", available at: http://www.elfaa.com/111221_ELFAA_PressRelease_EU_ETS_ECJ_Ruling.pdf (accessed 13 August 2012).

Eurostat (2013), "Database", available at: http://epp.eurostat.ec.europa.eu/portal/page/portal/transport/data/database (accessed 16 August 2013).

Ezard, K. (2008), "Seen to be green", Airline Business, Vol. 24 No. 1, pp. 48-51.

Flatters, P. and Willmott, M. (2009), "Understanding the post-recession consumer", Harvard Business Review, Jul/Aug2009, Vol. 87 Issue 7/8, pp. 106-112.

Flybe (n.d.a), "Low-cost but not at any cost", available at: http://www.flybe.com/en/corporate/sustainability/ (accessed 13 August 2012).

Flybe (n.d.b), "Eco-labelling scheme", available at: http://www.flybe.com/corporate/sustainability/eco_labelling_scheme.htm (accessed 13 August 2012).

Flybe (n.d.c), "Compare Flybe's fleet", available at: http://www.flybe.com/pdf/eco_labels_make_own.pdf (accessed 14 April 2014).

Flybe (n.d.d), "Message from Jim French". Flybe.

Flybe (n.d.f), "Emission trading scheme", available at: http://www.flybe.com/en/corporate/sustainability/emission_trading_scheme.htm (accessed 14 April 2014).

Flybe (n.d.e), "Flybe awards and accolades", available at: http://www.flybe.com/en/corporate/media/awards.htm (accessed 14 April 2014).

Flyvbjerg, B. (2011), "Case Study" in: Denzin, N.K. \& Lincoln, Y.S. (Eds.), The Sage handbook of qualitative research, Sage, Thousand Oaks.

Font, X. and Tribe, J. (2001), "Promoting Green Tourism: the Future of Environmental Awards", International Journal of Tourism Research, Vol. 3, pp. 9-21.

Fraj, E, Martínez, E. and Matute, J. (2011), "Green marketing strategy and the firm's performance: the moderating role of environmental culture", Journal of Strategic Marketing, Vol. 19 No. 4, pp. 339355.

Graham, A. (2008), "Trends and Characteristics of Leisure Travel Demand" in: Graham, A., Papatheodorou, A. and Forsyth, P. (Eds.), Aviation and Tourism : Implications for Leisure Travel. Ashgate, Aldershot.

Graham, A. (2014), Managing Airports, 4th ed., Routledge, London.

Graham, B. (2003), "Towards sustainable aviation?", in: Upham, P., Maughan, J., Raper, D. and Thomas, C. (Eds.), Towards Sustainable Aviation. Earthscan, London.

Grant, J. (2008), "Green marketing”, Strategic Direction, Vol. 24 No. 6, pp. 25-27.

Gray, D.E. (2014), Doing research in the real world, SAGE Publications, London.

Grayson, M. (2011), "Biofuels", Nature, Vol. 474, p. S1. 
Green Power Conferences (2013), "Sustainable Biofuels Awards 2013: WINNERS Announced", available at:

http://www.worldbiofuelsmarkets.com/EF/?sSubSystem=Prospectus\&sEventCode=BA1303NL\&sS essionID=c9ce5b59dccde324fe9ebc0c4b0ea15a-19619639 (accessed 14 April 2014).

Greenpeace (2008). "Virgin guilty of 'high altitude greenwash'”, available at: http://www.greenpeace.org.uk/media/press-releases/virgin-guilty-of-high-altitude-greenwash20080224 (accessed 14 April 2014).

Grundy, M. and Moxon, R. (2013), "The effectiveness of airline crisis management on brand protection: A case study of British Airways", Journal of Air Transport Management, Vol. 28, pp. 5561.

Harrison, A. (2007), "Airlines must play their part in saving the planet", Financial Times, 14 February 2007, p. 15.

Hartmann, P., Apaolaza Ibáñez, V. and Forcada Sainz, F. J. (2005), "Green branding effects on attitude: functional versus emotional positioning strategies", Marketing Intelligence \& Planning, Vol. 23 No. 1, pp. 9-29.

Hayward, N. and Carbery, S. (2007), "Searching for greener pastures", Brand Strategy, May 2007, pp. 42-43.

Hickman, M. (2010), "Global warming? It doesn't exist, says Ryanair boss O'Leary", available at: http://www.independent.co.uk/environment/climate-change/global-warming-it-doesnt-exist-saysryanair-boss-oleary-2075420.html (accessed 14 April 2014).

Hodgson, N. (2007), "Eco-friendly planes are set for take-off", Liverpool Echo, 15 June 2007, p. 24.

Holden, A. (2009), "The Environment-Tourism Nexus: Influence of Market Ethics", Annals of Tourism Research, Vol. 36 No. 3, pp. 373-389.

Holloway, S. (2008), Straight and Level: Practical Airline Economics, 3rd ed., Ashgate, Aldershot.

Hooper, P., Daley, B., Preston, H and Thomas, C. (2008), "Final OMEGA Report: An Assessment of the Potential of Carbon Offset Schemes to Mitigate the Climate Change Implications of Future Growth of UK Aviation", available at: http://www.omega.mmu.ac.uk/Downloads/FinalReports/5\%20Final\%20Report\%20Potential\%20Carbon\%20Offsetting\%20to\%20Mitigate\%20Clim ate $\% 20$ Change $\% 20 \% 20$ Implications.pdf (accessed 12 February 2011).

Hunt, N. (2008), "Nuts help fuel first biofuel flight", available at: http://uk.reuters.com/article/2008/02/25/environment-britain-branson-flight-dcidUKL2451986620080225 (accessed 14 April 2014).

Hunt, S. D. (2010), Marketing Theory: Foundations, Controversy, Strategy, Resource-Advantage Theory, M.E. Sharpe, Armonk.

IATA (2011), "A Waste of Waste", available at: http://www.iata.org/publications/airlinesinternational/december-2011/Pages/waste.aspx (accessed 14 April 2014).

IPCC (1999), Aviation and the Global Atmosphere. Cambridge University Press, Cambridge.

Jiang, H. (2013), "Service quality of low-cost long-haul airlines - The case of Jetstar Airways and AirAsia X", Journal of Air Transport Management, Vol. 26, pp. 20-24.

Jones, S., and Milmo, D. (2008), "Aviation: Branson's coconut airways - but jet is on a flight to nowhere, say critics: Environmental groups raise doubts over plane that runs partly on biofuel", The Guardian, 25 February 2008, p. 11.

Klassen, R. D. and McLaughlin, C. P. (1996), "The Impact of Environmental management on Firm Performance", Management Science, Vol. 42 No. 8, pp. 1199-1214.

Kling, M. and Hough, I. (2011), Air Travel Carbon And Energy Efficiency, Brighter Planet, Vermont.

Kotler, P. (2011), "Reinventing Marketing to Manage the Environmental Imperative", Journal of Marketing, Vol. 75, pp. 132-135.

Kotler, P. and Keller, K. L. (2012), Marketing Management. 14th ed., Pearson Education, Harlow.

Laforet, S. (2010), Managing Brands: A Contemporary Perspective, McGraw Hill, Maidenhead.

Leonidou, C.N. and Katsikeas, C.S. (2013), "'Greening" the marketing mix: do firms do it and does it pay off?", Journal of the Academy of Marketing Science, Vol. 41 No. 2, pp. 151-170.

Lufthansa (2013), "Resource efficiency at zero altitude", available at: http://www.lufthansagroup.com/index.php?id=322\&tx_ttnews(tt_news) $=2341 \& \mathrm{~L}=1 \&$ print $=1 \&$ no_ca che $=1$ (accessed 14 April 2014).

Lynes, J. K. and Dredge, D. (2006), "Going Green: Motivations for Environmental Commitment in the Airline Industry. A Case Study of Scandinavian Airlines", Journal of Sustainable Tourism, Vol. 14 No. 2, pp. 116-138.

Marsh, G. (2008), "Biofuels: aviation alternative?", Renewable Energy Focus, Vol. 9, pp. 48-51.

Mason, K. and Miyoshi, C. (2009), Airline Business Models and their respective carbon footprint: Final Report, Omega, Manchester Metropolitan University. 
Mayer, R., Ryley, T. and Gillingwater, D. (2012), "Passenger perceptions of the green image associated with airlines", Journal of Transport Geography, Vol. 22, pp. 179-186.

McCartney, G. (2008), "Does one culture all think the same? An investigation of destination image perceptions from several origins", Tourism Review, Vol. 63 No. 4, pp. 13-26.

Meikle, J. (2011), "Virgin Atlantic unveils plan to use 'green' fuel", available at: http://www.guardian.co.uk/environment/2011/oct/11/virgin-atlantic-green-fuel (accessed 14 April 2014).

Millward, D. (2007), "Easyjet unveiled 'eco-jet' design", available at: http://www.telegraph.co.uk/earth/earthnews/3297417/Easyjet-unveiled-eco-jet-design.html (accessed 14 April 2014).

Milmo, D. (2007), "EasyJet unveils 'ecoJet'", available at: http://www.guardian.co.uk/environment/2007/jun/14/theairlineindustry.business (accessed 14 April 2014).

Minkiewicz, J., Evans, J., Bridson, K. and Mavondo, F. (2011), "Corporate image in the leisure services sector", Journal of Services Marketing, Vol. 25 No. 3, pp. 190-201.

Nygren, E., Aleklett, K. and Höök, M. (2009), "Aviation fuel and future oil production scenarios", Energy Policy, Vol. 37, pp. 4003-4010.

O'Connell, J. F. and Williams, G. (2005), "Passengers' perceptions of low-cost airlines and full service carriers: A case study involving Ryanair, Aer Lingus, Air Asia and Malaysia Airlines”, Journal of Air Transport Management, Vol. 11, pp. 259-272.

O'Connell, J. F. and Williams, G. (2006), "Transformation of India's Domestic Airlines: A case study of Indian Airlines, Jet Airways, Air Sahara and Air Deccan", Journal of Air Transport Management, Vol. 12, pp. 358-374.

Osborne, H. (2007), "Budget airline launches 'eco-labels' for planes", available at: http://www.theguardian.com/business/2007/jun/04/theairlineindustry.travelandtransport (accessed 14 April 2014).

Ottman, J. A. (2011), The New Rules of Green Marketing, Greenleaf Publishing, Sheffield.

Pank, P. (2011), "Branson plans to turn Virgin flights green", The Times, 12 October 2011, p. 13.

Pearce, F. (2009), "Greenwash: easyJet's carbon claims written on the wind", available at: http://www.guardian.co.uk/environment/blog/2009/jul/23/easyjet-climate-change-claims (accessed 14 April 2014).

Peattie, K. (1995), Environmental Marketing Management: Meeting the Green Challenge, Pitman Publishing, London.

Prosser Deputy, D. (2007), "EasyJet says new design will slash CO2 emissions in half", The Independent (Business), 15 June 2007, p. 1.

Rabinovich, E. and Cheon, S. (2011), "Expanding Horizons and Deepening Understanding via the Use of Secondary Data Sources", Journal of Business Logistics, Vol. 32 No. 4, pp. 303-316.

Robbins, T. (2007), "Escape: the hot topic: 'ecoJet' is pie in the sky, say environmentalists", The Observer, 17 June 2007, p. 4.

Rye, L., Blakey, S. and Wilson, C. W. (2010), "Sustainability of supply or the planet: a review of potential drop-in alternative aviation fuels", Energy \& Environmental Science, Vol. 1, pp. 17-27.

Ryerson, M. S. and Hansen, M. (2010), "The potential of turboprops for reducing aviation fuel consumption", Transportation Research D, Vol. 15, pp. 305-314.

Saha, M and Darnton, G. (2005), "Green Companies or Green Con-panies: Are Companies Really Green, or Are They Pretending to Be?", Business and Society Review, Vol. 110 No. 2, pp. 117157.

SAS (2009), "SAS environmental goals and strategies (online video)", available at: http://www.youtube.com/watch?v=R5UDqS_4iss (accessed 14 April 2014).

Sgouridis, S., Bonnefoy, P. A. and Hansman, R. J. (2011), "Air Transportation in a carbon constrained world: Long-term dynamics of policies and strategies for mitigating the carbon footprint of commercial aviation", Transportation Research Part A, Vol. 45, pp. 1077-1091.

Shaw, S. (2011), Airline Marketing and Management, 7th ed., Ashgate, Aldershot.

Somerville, H. (2003), “Transport Energy and Emissions: Aviation”, in: Hensher, D. A. and Button, K. J. (Eds.), Handbook of Transport and the Environment, Elsevier, Oxford.

South China Morning Post (2011), "Virgin to use jet fuel made from steel mill waste gas". South China Morning Post, 24 October 2011, p. 1.

Strategic Direction (2010), "When branding gets personal: Big names who stamp identity on their companies", Strategic Direction, Vol. 26 No. 4, pp. 28-31.

Strategic Direction (2013), "Shades of green in risk and value", Strategic Direction, Vol. 29 No. 6, pp. 5-7. 
The Co-operative Group (2012). Ethical consumer Markets Report 2012 (online), The Co-operative Group. Available at: http://www.co-operative.coop/PageFiles/416561607/Ethical-ConsumerMarkets-Report-2012.pdf (accessed 14th April 2014)

The Guardian (2009), "George Monbiot meets easyjet chief executive Andy Harrison (online video)", available at: http://www.youtube.com/watch?v=hhpTr_ZJ4Gk (accessed 14 April 2014).

Tight, M. (2010), "The curious case of case study: A viewpoint", International Journal of Social Research Methodology, Vol. 13 No. 4, pp. 329-339.

Van der Zwan, F. and Bhamra, T. (2003), "Services marketing: taking up the sustainable development challenge", Journal of Services Marketing, Vol. 17 No. 4, pp. 341-356.

Virgin Atlantic (2006), "Virgin Atlantic's plans to cut carbon emissions gain ground as airports prepare for December trials", available at: http://www.virginatlantic.com/en/gb/allaboutus/pressoffice/pressreleases/news/pr041206c.jsp (accessed 14 April 2014).

Virgin Atlantic (2010), Sustainability Report Autumn 2010 (online), Virgin Atlantic. Available at: http://www.virgin-atlantic.com/corporate/images/vaa_sustainability_report_autumn_2010.pdf (accessed 14th April 2014).

Virgin Atlantic (2011), "Sustainability Report Winter 2011/2012", available at: http://www.virginatlantic.com/corporate/images/newsustainabilityreport.pdf (accessed 14 April 2014),

Webster, B. (2008), "Virgin's green idea loses its pulling power", The Times, 10 March 2008, p. 23.

Wilson, A., Zeithaml, V. A., Bitner, M. J. and Gremler, D. D. (2008), Services Marketing: Integrating customer focus across the firm, McGraw-Hill, Maidenhead.

Xiao, H. and Smith, S.L.J. (2006), "Case studies in tourism research: A state-of-the-art analysis", Tourism Management, Vol. 27 No. 5, pp. 738-749

Yin, R. K. (2009), Case Study Research: Design and Methods, 4th ed., Sage, Thousand Oaks.

\section{Author biographies}

Robert Mayer, PhD, is a Lecturer in Air Transport Management at the Centre for Air Transport Management at Cranfield University.

Tim Ryley, PhD, is a Senior Lecturer in Transport Studies within the School of Civil and Building Engineering at Loughborough University in the UK.

David Gillingwater, PhD, is an Honorary Fellow in Transport Studies within the School of Civil and Building Engineering at Loughborough University in the UK. 